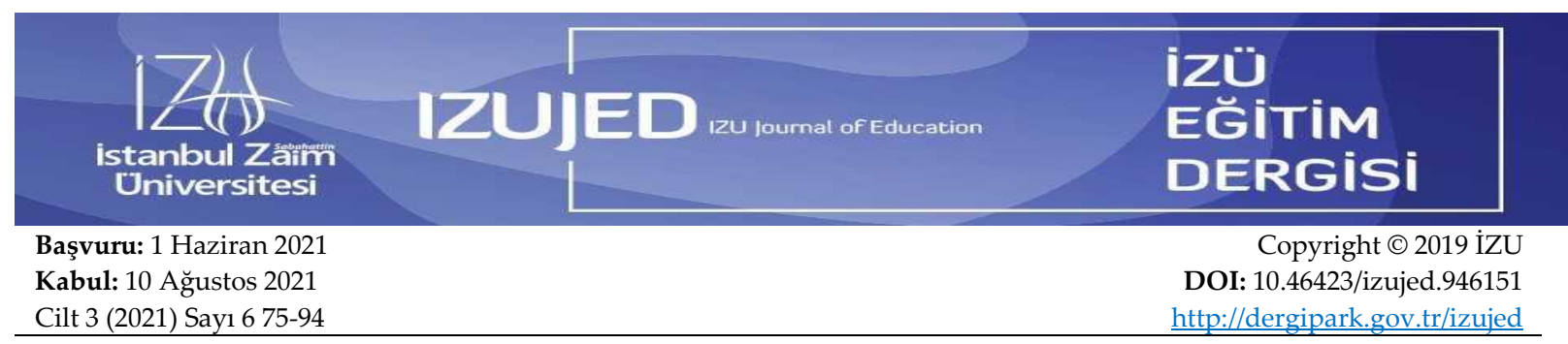

\title{
Uzaktan Eğitim Uygulamalarının Ortaöğretim Öğrencilerindeki Öğrenme Düzeylerine Etkisinin İncelenmesi
}

Ömer Tevetoğlu ${ }^{1}$

\author{
Tuncay Akçadağ²
}

Öz

Bu çalışmanın amacı, ortaöğretim öğrencilerinin uzaktan eğitim süreçlerine hazırbulunuşluk düzeyleri ile uzaktan eğitim süreçlerinde öğrenme düzeyleri arasındaki ilişkinin incelenmesidir. Bu araştırmada nicel araştırma modellerinden ilişkisel tarama, korelasyon yöntemi kullanılmıştır. Araştırmanın örneklemi İstanbul İli Maltepe İlçesi ortaöğretim kurumlarında eğitimlerine devam eden 389 öğrenciden oluşmaktadır. Veri toplama aracı olarak Gülbahar (2012) tarafından geliştirilen “E-Öğrenme Sürecine İlişkin Hazırbulunuşluk ve Beklenti Düzeyi Ölçeği" ve "E-Öğrenme Sürecine İlişkin Memnuniyet Ölçeği" kullanılmıştır. Verilerin analizinde ilk olarak verilere ait frekans, yüzde dağılımları, aritmetik ortalama ve standart sapma istatistiki değerleri hesaplanmıştır. Verilerin homojen dağılıma sahip olduklarının tespitiyle değişkenler arasındaki farklılığı ortaya koyabilmek için ikili karşılaştırmada parametrik testlerden $\mathrm{t}$-Testi, ikiden fazla grupların karşılaştırılmasında tek yönlü varyans analizi (ANOVA) kullanılmıştır. Farklılıkların anlamlı bulunması durumunda hangi gruplar arasında olduğunun tespiti için post-hoc LSD testi uygulanmıştır. Analizler sonucu ortaöğretim öğrencilerinin uzaktan eğitim süreçlerine hazırbulunuşluk düzeylerinin yüksek olduğu, Fen Lisesi öğrencilerinin hazırbulunuşluk düzeylerinin diğer okul türlerine göre anlamlı bir farklılık gösterdiği tespit edilmiştir. Ortaöğretim öğrencilerinin hazırbulunuşluk düzeylerinin arttırılması için Milli Eğitim Bakanlığı tarafından kullanılan EBA(Eğitim Bilişim Ağı) sisteminin ders yılı başlangıcında zorunlu katılımın sağlanacağı interaktif eğitimler ile verilmesi gerekmektedir.

Anahtar Kelimeler: Uzaktan eğitim, hazırbulunuşluk ve memnuniyet

\section{Investigation Of The Effect Of Distance Education Applications On Learning Levels Of Secondary School Students}

\begin{abstract}
The aim of this study is to determine the relationship between the readiness levels of secondary school students for distance education processes and their learning levels in distance education processes. In this study, one of the quantitative research models, relational survey, correlation method was used. The sample of the research consists of 389 students who continue their education in secondary education institutions in Maltepe District of Istanbul. As the data collection tool developed by Gülbahar (2012) the "Readiness and Expectation Level Scale for the E-Learning Process" and "Scale for Satisfaction with the E-Learning Process" were used. In the analysis of the data, first of all the frequency, percentage
\end{abstract}

${ }^{1}$ Öğretmen, Mehmet Salih Bal Mesleki ve Teknik Anadolu Lisesi, omertevetoglu@gmail.com ORCID: 0000-0002-6142-4689

${ }^{2}$ Prof. Dr., Fatih Sultan Mehmet Vakıf Üniversitesi, takcadag@fsm.edu.tr ORCID: 0000-0002-9131-2039 Atıf: Tevetoğlu, Ö. ve Akçadağ, T., (2021) . Uzaktan Eğitim Uygulamalarının Ortaöğretim Öğrencilerindeki Öğrenme Düzeylerine Etkisinin İncelenmesi, İZü Ĕ̆itim Dergisi, 3(6) 75-94.

DOI: 10.46423/izujed.946151 
distributions, arithmetic mean and standard deviation statistical values were calculated. T-Test, one of the parametric tests, was used in pairwise comparison, and one-way analysis of variance (ANOVA) was used in the comparison of more than two groups in order to reveal the difference between the variables by determining that the data had a homogeneous distribution. If the differences were found to be significant, the post-hoc LSD test was applied to determine between which groups.

As a result of the analyzes, it was determined that the readiness level of the secondary school students for the distance education processes was high, and the readiness levels of the Science High School students showed a significant difference compared to the other school types.

In order to increase the readiness level of secondary school students, the EBA (Educational Information Network) system used by the Ministry of National Education should be provided with interactive trainings at the beginning of the academic year, in which compulsory participation should be ensured.

Keywords: Distance education, readiness for distance education, satisfaction with distance education

\section{Extended Abstract}

\section{Introduction}

In the 21st century, the increase in the numerical presence of people who hope to develop and train themselves in all areas of education and life and are aware of the fact that they can achieve this through education has resulted in the differentiation, diversification and becoming much more comprehensive in every field of education. Education and training activities, where there is no limitation of time and space, that can appeal to every age and everywhere, and that allow people to learn lifelong, started (Koloğlu, 2016). The fact that distance education and training activities have removed the limits of space and time is widely used in our age in terms of providing lifelong learning, and its economic dimension makes it inevitable. In this age when it is difficult to keep up with the pace of technological transformation and change, distance education, which can be an alternative to face-to-face and school education, has become indispensable (Burrell \& Morgan, 1979; Koçyiğit \& Uşun, 2020). In the Covid-19 pandemic process, distance education has become a method of application in terms of being an easy method to apply and ensuring the continuity of educational activities.

\section{Method}

This research, which is conducted to examine the effects of distance education applications on the learning levels of secondary school students, is a quantitative research study that tries to demonstrate the efforts of explanation using the relational scanning model. Relational screening model is used to describe the effects of students studying in secondary education institutions, which are the source of the subject, on their education levels during distance education in terms of personal qualities, access to technology, technology use skills, motivation and attitude, success and satisfaction.

The use of simple and random sampling method was deemed appropriate in this study. The universe of the research; In the second period of the 2020-2021 academic year, a total of 17134 students studying in secondary education institutions in Maltepe district of Istanbul province, and the sample consists of secondary education students studying in schools affiliated to Maltepe MEM in Istanbul. In the study, the scale was applied to 389 secondary school students studying in Maltepe district.

\section{Findings And Discussion}


It has been observed that secondary education students have higher levels of technical skills among the readiness dimensions of distance education processes. According to another result obtained in line with the findings, it is seen that secondary school students have medium level skills in transmission and usefulness, which are among the readiness dimensions of distance education processes. It was concluded that the expectation levels of the students about distance education processes are high in the factors affecting success. It has been concluded that there is no significant difference according to their gender in the readiness and expectations of students in relation to distance education processes. It was determined that there is a moderately significant positive correlation between students' level of readiness and expectation regarding the distance education process and their satisfaction. Finally, it was concluded that the readiness and expectation levels of students regarding the distance education process predicted their satisfaction

\section{Giriş}

Bilişim teknolojilerindeki gelişmeler çă̆ itibariyle, hayatın her alanını etkilemekle birlikte özellikle eğitim alanında kalıcı ve köklü değişimler yaşanmasına zemin hazırlamıştır. Bunlardan biri de bilgiye ulaşabilme konusunda uzam, zaman, yaş vb. faktörlerden kaynaklanan engelleri ortadan kaldırıp kişilerin yaşam boyu öğrenebilmesine imkân tanıyan uzaktan eğitim kavramının da giderek yaygın hâle gelmesidir. Uzaktan eğitim, öğrenme süreçlerinde öğrenci ve öğretmenin farklı uzamlarda olduğu, öğrenciye eğitim ortamı, eğitim zamanı ve eğitim mekânı bakımından bireysellik, bütüncül bağımsızlık ve esnek çalışma imkânı sunabilen sistemli bir eğitim ve öğretim teknolojisidir (Uşun, 2006).

Tarihî seyir içerisinde eğitim sistemleri bakımından, birçok teknik, yöntem ve strateji kullanılagelmiş, teknolojik ve bilimsel gelişmeler ve toplumların da insanların da değişen ihtiyaç ve talepleri bağlamında her dönemde, farklı farklı öğrenme ve öğretme ortamları önemini ortaya koymuştur (Topçu, 2017). 21. yüzyılın bilgi toplumunda, bilişim ve teknoloji alanlarında ortaya çıkan devasa dönüşüm, değişim ve gelişim de yeni kavramlar ortaya çıkarmıştır ki bunlardan biri uzaktan eğitimdir (Aker, 2002; Yıldız, 2016). Uzaktan eğitim, süregelen öğretim ve öğrenme yöntemlerinin sınırlı oluşu sebebiyle sınıf ortamındaki faaliyetlerin gerçekleştirilme imkânının olmadığı durumlarda, öğretim ve eğitim faaliyetlerini planlayanlar ile gerçekleştirenler yani öğrenciler arasında etkileşimin ve iletişimin hususi olarak hazırlanan öğretim birimleri ve farklı uzamlar vasıtasıyla bir ana merkezden öğretme biçimi; yöntemidir (Ak, Oral ve Topuz, 2018; Kaya, 2002). İçten'e (2006) göre uzaktan eğitimin; alışılagelmiş klasik eğitim sorunlarına yönelik meydana çıkan, eğitim faaliyetlerinin düzenlendiği, öğretmenler ile öğrenciler arasındaki etkililiği sağlamak için geliştirilen özel yöntemler ve ortamlar kullanan kurumlar tarafından uygulanan eğitim yöntemidir.

Uzaktan öğretim faaliyetlerinin başlıca dayanakları ise; kişilerin birbirinden bağımsız ve farklı eğitim-öğretim imkânları ihtiyacına sahip olması, süregelen uygulama yöntemlerinin bu ihtiyaca cevap verememesi, süregelen yöntemlere yeni imkânlar eklenerek bağımsız ve şahsî bir öğrenme ile kapsamlı ve kitlesel bir eğitim sağlanmasıdır. Oluşturulan bu farklı seçenekler, süregelen ve gelenekli hâle gelmiş eğitim-öğretim faaliyetlerinin yeterli olmaktan uzak oluşunu gidererek bütün kesimlerin ve bireylerin eşit bir biçimde eğitim-öğretimden yararlanmalarını sağlamaktır. Dünyanın birçok ülkesinde, farklı türlerdeki eğitim-öğretim problemlerinin ortak çözümü uzaktan eğitim faaliyetleri olmuştur (Cowles, 1989; Curabay ve Demiray, 2002; Dündar, vd., 2017: 201). Uzaktan eğitim faaliyetinde e-posta, telekonferans yahut bilgisayarlı konferans ve internet ağı gibi çok mekânlı sunum sistemlerinden 
faydalanılmaktadır. Bu sistem ve sistem araçlarıyla, öğretenler öğrenenlere, öğrenenler öğretenlere ve öğrenenler öğrenenlere sorular ve yanıtlar gönderip, onlardan alabilmektedir (Kaya, 2002). Uzaktan eğitim; eğitimin daha büyük ve geniş toplumsal kitlelere götürülmesi, eğitimde imkân ve fırsat eşitlenmesinin sağlanması, bireylerin şahsî ihtiyaçlarına yönelik basit güncellemelere imkân tanıması, eğitimdeki ekonomik maliyetleri düşürmesi, farklı ortamlardaki uzmanlardan faydalanabilmesi ve öğrenen kişi merkezli olması açısından süregelen yöntemlere göre avantajlı bir yapı çizmektedir (Gökçe, 2008; Şen, Atasoy ve Aydın, 2010).

Uzaktan eğitimin sahip olduğu özellikler arasında aşağıdaki maddeler sıralanabilir:

- Uzaktan eğitim faaliyetleri kurumlar aracıllğı ile gerçekleştirilen öğretici ile yapılan akademik eğitimlerdir.

- Mekân sınırlamasının olmamasından dolayı eğitime erişim konusunda esneklik olumlu yönüdür.

- Öğrenci ve öğretmenler arasında etkili iletişim sağlamasından dolayı grubu oluşturan üyeler arasında bağ oluşumunu sağlar.

- Uzaktan eğitim, öğretmen, öğrenci ve öğrenme materyallerinden oluşan bir toplululk olduğundan dolayı sosyal ağ/topluluk oluşturmasına yöneltir (Berg ve Simonson, 2016).

Uzaktan eğitim, yukarıda belirtilen özelliklerin yanı sıra sınırlılıkları da mevcuttur: öğretmen ve öğrenci toplulukları arasında iletişimin kurulmasının zor olması, öğrencilerin sosyal faaliyetlerinin sınırlanmasına neden olması, kişisel öğrenme alışkanlığına sahip olmayan bireylerde etkin olmaması, aynı zamanda çalışmak zorunda olan öğrencilerin kendilerine ayırmış oldukları zamanı sınırlama, ders içeriklerinin uygulama olan bölümlerinde istendik sonuçların alınamaması, yetenek ve tavır kazanımlarını sağlamaya yönelik alışkanlıklarına katkı sağlayamama, ulaşım ve teknolojik altyapıya ait donanımlara bağımlı olma (Bolliger ve Martin, 2018; Kaya, 2002).

Uzaktan eğitimin öğretim ortamı, belli başlı yazılımların kullanılmasıyla oluşmuş bir sistem vasıtasıyla sağlanır. Bu sistem, çevrimiçi ağ vasıtasıyla öğretim ortamının yönetimini sağlar ve öğretme-öğrenme faaliyeti için belirli değişkenleri bir araya getiren bir sistem hâlini alır (Altunc1 vd., 2009; Curabay ve Demiray, 2002; Haznedar ve Baran, 2012; Nichols, 2003). Farklı bir deyişle, öğretim programı ve derslerin çevrimiçi ağ üzerinden bazen eş zamanlı bazen de eş zamansız hâliyle yürütüldüğü, kullanıcıya öğretim ortamında birçok imkân (mesajlaşma, rapor alma, ödev verme, anket, tartışma ve forum, etkileşimli sanal sunumlar, öğrenme materyali paylaşma, ekleme, düzenleme, video, animasyon) tanıan bir uzaktan eğitim faaliyeti yazılımı olarak da tanımlanabilir.

Farklı mesafelerde gerçekleştirilen bu eğitim faaliyetlerinde öğretmen, öğrenci ve öğretim materyalleri etkili bir etkileşime sahiptir (İçten, 2006; Moore, 1989; Ural, 2005; Yıldız, 2015). Nitekim Garrison, Anderson ve Archer'a (2000) göre uzaktan eğitim platformlarında öğrencinin duyuşsal nitelikleri gerekli olan ilgiyi göstermediğini belirtmelerine rağmen; öğretmen, öğrenci ve öğretim materyalleri arasındaki etkileşim gücü öğrencinin tutum ve güdülemesini olumlu yönde etkilemektedir. Cookson'a (1989) göre ise de uzaktan eğitim uygulamalarında donanımsal yöntemlerin öne çıtı̆̆ını öğrencilerin ruhsal ve sosyal durumlarına yönelik çalışmaların yeterli olmadığını belirtmiştir. 
Uzaktan eğitim modelleri, Dünya genelinde var olan Covid-19 pandemi sürecinde uygulaması kolay bir yöntem olması ve eğitim faaliyetlerinin sürdürülebilmesini sağlaması açısından başvurulan bir yöntem haline gelmiştir. Pandemi sürecinin yarattığı kriz ortamına rağmen son derece hızlı bir çözüm olmuş; yüz yüze eğitime uygun yapılandırılmış eğitim kurumları dahi bu eğitim yöntemi yerine web tabanlı uzaktan eğitim dersleri vasıtasıyla programlarını devam ettirebilmek için hızlı bir biçimde çalışmaya koyulmuş ve son derece hızlı bir biçimde bu geçiş süreci tamamlamıştır (Lau, Yang ve Dasgupta, 2020).

Pandemi sürecinde birçok ülke gibi Türkiye'de de eğitim faaliyetlerine ara verme kararı almıştır. Covid-19 pandemi sürecinden dolayı eğitim kurumlarının eğitim faaliyetlerine ara vermesi ve bu sürecin uzama olasılığının yüksek olması, eğitim faaliyetlerini devam ettirmek için farklı seçeneklerin ortaya çıkarılmasını neden olmuştur. Millî Eğitim Bakanlığı (MEB) tarafından daha önce kullanılan Eğitim Bilişim Ağı (EBA) üzerinden eğitimin devam ettirilmesini gündeme getirilmiş ve sistemin sahip olduğu içeriklerin geliştirilmesine başlanmıştır. Milyonlarca öğrencinin pandemi sürecinde dışarı çıkamamasından dolayı eğitim faaliyetlerinin çevrimiçi ortamlarda yapılmasını hızlandırmıştır. Bu süreçte EBA ve diğer uzaktan eğitim platformları önemli bir işlevi yerine getirmeye başlamıştır (Demir ve Özdaş, 2020). EBA, Yenilik ve Eğitim Müdürlüğü (YEGITEK) bünyesinde yapımı ve gelişimi yapılan, çerçeve eğitim programları doğrultusunda öğretim materyallerine uygun içeriklerin öğrenci ve öğretmenlerin kullanımına sunulduğu internet altyapısına sahip ortamdır (Aktay ve Keskin, 2020). MEB, Pandemi koşullarından dolayı 23 Mart 2020 tarihinde uzaktan eğitime başlamış ve uzaktan eğitim faaliyetlerini sağlayabilmek için EBA'nın sahip olduğu eğitim materyallerini çoğaltmış ve öğretmenler aracılığı ile çerçeve eğitim programlarına uygun videolar hazırlanmıştır. Türkiye'de eğitimde fırsat eşitliğini sağlayabilmek adına internet kullanımının gerek altyapı gerekse ekonomik nedenler ile gerçekleştirilemediği yerler için TRT EBA kanalları yayın hayatına başlatılmıştır. Bu kanallar yolu ile eğitimin her düzeyinde bulunan öğrenciler için ders anlatımları yapılmıştır. TRT EBA'nın yanı sıra EBA'nın internet sitesine ulaşılmasını sağlamak için telekomünikasyon firmaları ile anlaşarak sınırlı düzeyde ücretsiz internet hizmeti öğrencilerinin hizmetine sunulmuştur (Emin, 2020).

MEB, EBA, TRT EBA üzerinden başlatılan uzaktan eğitim çalışmaları, EBA üzerinden "canlı ders uygulaması" olarak tüm sinıf düzeylerinde belirli saatlerde uygulanmak üzere devam ettirilmiştir (Can, 2020). Öğrenci-öğretmen etkileşiminin sağlanmasına yardımcı olan bu uygulama internet aracılığı ile ders faaliyetlerinin yapılabilmesine imkân vermiştir. İlk zamanlarında 8. ve 12. sınıf düzeyleri için kullanıma açılan sistem ilerleyen zamanlarda tüm eğitim kademeleri için kullanıma sunulmuştur. Bu hamleler sonucu doğrultusunda uzaktan eğitim kavramı, eğitimi oluşturan tüm hissedarların hayatında önemli bir konum sahibi olmaya başlamıştır.

$\mathrm{Bu}$ geçiş süreci son derece hızlı gerçekleştiği için öğrencilerde olduğu gibi eğitimciler için de uzaktan eğitimin şartlarına ve gereklerine uyum sağlamaları hususunda sınırlı sayıda değerlendirme çalışması yapılabilmiştir (Akdemïr ve Kılıç, 2020; Aktay ve Keskin, 2020; Başaran, Doğan, Karaoğlu ve Şahin, 2020; Can, 2020; Dikmen ve Bahçeci, 2020; Demir ve Özdaş, 2020; Emin, 2020; Keskin ve Kaya, 2020; Tellï ve Altun, 2020). Gelişen bilişim teknolojileriyle beraber, hem öğretim programları, hem öğrenen ihtiyaçları, hem de öğretim programları ile bu programlarda kullanılagelen strateji, teknik ve yöntemler sürekli bir dönüşüm, değişim ve gelişim içerisindedir. Bu gelişmeler; öğrenenlerin isteklerinde ve 
ihtiyacında, eğitimin işlevsel yönünde, öğretenin rollerinde ve öğretim yöntemlerinde değişikliklere sebep olmaktadır (Çoban, 2013; Orhan ve Akkoyunlu, 1999).

Yapılan tüm teknolojik çalışmalar bilgiye erişimde eşitlik sağlanamadığ öğrencinin okuldan uzak bir öğrenme iklimine adapte olup olmamasının yanında bazı soruları da beraberinde getiriyor: EBA temelli uzaktan eğitim temel kazanımların gerçekleştirilmesinde etkili mi? EBA'nın; MEB tarafından yayınlanan Millı̂ Eğitim Kalite Çerçevesinde yer alan “Öğrenci Temel Öğrenme Kazanımları” gerçekleştirilmesinde etkisi ne ölçüde? Gelecekte teknolojinin eğitimde etkin olarak kullanılacağı düşünüldüğünde teknolojinin öğrenci öğrenmesinin sağlamasında oynadığı rol üzerine yapılan bu araştırmanın hem alan yazınına hem de gelecekteki eğitim ve yönetici seçme politika ve yöntemlerine 1şık tutmayı haiz bir araştırma olacağı ortadadır. Araştırmanın yapıldığı süreçte uzaktan eğitim faaliyetlerinin devam etmesi ve Covid-19 salgının durumuna göre gelecekte eğitim-öğretim sürecinde başvurulacak yöntemlerden biri olması uzaktan eğitimi değerli kılmaktadır. Ayrıca var olan uzaktan eğitim sisteminin analiz edilmesinin sistemin geliştirilmesine yardımcı olacaktır. Geleneksel eğitime alternatif olduğu düşünülen, kurumların sinırlılıklarını ortadan kaldıracağı öngörülen uzaktan eğitim sisteminin istendik gelişmelere ulaşıp ulaşmayacağı da cevabı beklenen sorular arasındadir.

En önemli hayati kavramlardan biri olan eğitimin ne şekilde yapıldığ 1 ve ne düzeyde verim alındığı gibi konuların incelenmesi, bu noktada, uzaktan eğitimde öğrencilerin onları hayata ve bir üst öğrenim kademesine hazırlanmalarında gerekli olan eğitim yönteminin incelenmesinin gerekliliği ortaya çıkmaktadır. Bu araştırmada "Uzaktan Eğitim Uygulamalarının Ortaöğretim Öğrencilerindeki Öğrenme Düzeylerine Etkisi nasıldır?” problemine yanıt bulunmaya çalışılmıştır. Bu problem altında;

1. Öğrencilerin uzaktan eğitim süreçlerine ilişkin hazırbulunuşlukları ne düzeydedir?

2. Öğrencilerim uzaktan eğitim süreçlerine ilişkin beklentileri ne düzeydedir?

3. Öğrencilerin uzaktan eğitim süreçlerine ilişkin hazırbulunuşluk ve beklenti düzeyleriyle uzaktan eğitim süreçlerine ilişkin memnuniyetleri cinsiyetlerine, sınıf düzeylerine ve eğitim aldıkları okul tiplerine göre anlamlı farklılık göstermekte midir?

4. Öğrencilerin uzaktan eğitim süreçlerine ilişkin hazırbulunuşluk ve beklenti düzeyleri, uzaktan eğitim süreçlerine ilişkin memnuniyetleri arasında anlamlı bir ilişki bulunmakta mıdır?

5. Öğrencilerin uzaktan eğitim süreçlerine ilişkin hazırbulunuşluk ve beklenti düzeyleri, uzaktan eğitim süreçlerine ilişkin memnuniyetlerini anlamlı bir şekilde yordamakta midir?

Sorularına cevap aranmıştır.

\section{Yöntem}

$\mathrm{Bu}$ bölümde araştırmanın modeli, evren ve örneklem, veri toplama araçları ile verilerin toplanması ve analizi yer almaktadır.

\section{Araştırmanın Modeli}


Araştırma nicel yöntemlerle yürütülmüştür. Nicel araştırmalar, bağımlı değişken veya değişkenlerin araştırma sonucunda elde edilen sayısal verilerin istatistiksel olarak inceleyen bilimsel çalışmalardır. Uzaktan eğitim uygulamalarının ortaöğretim öğrencilerindeki öğrenme düzeylerine etkisinin incelenmesi amacıyla yapılan bu araştırmada ilişkisel tarama modeli kullanılmıştır. İlişkisel tarama modeli, dar zaman aralığında çok fazla katılımcıya ulaşarak, katılımcıların araştırma konusu çerçevesinde görüş ve yaklaşımlarını almak, alınan dönütler doğrultusunda araştırma konusunu tanımlamalar yapmak ve araştırmak olup, bu işlem basamakları sonucunda değişkenler arasında var olan bağıntıları ortaya koyak hedefleri ile uygulanır (Karasar, 2018).

\section{Evren ve Örneklem}

Araştırmanın evreni; 2020- 2021 eğitim-öğretim yılı 2. döneminde İstanbul ili Maltepe ilçesindeki 2 fen lisesi, 1 sinav ile öğrenci alan Anadolu lisesi, 6 anadolu lisesi, 7 anadolu meslek lisesi ve 6 anadolu imam-hatip lisesinde öğrenim gören 5711 9. sinıf , 4543 10. sınıf , 3832 11. sınıf ve 3048 12. sınıf olmak üzere toplam 17134 öğrenci, örneklemini ise İstanbul ili Maltepe MEM'e bağlı olan okullarda öğrenim gören ortaöğretim öğrencileri oluşturmaktadır. Araştırmada Maltepe ilçesinde öğrenim gören 389 ortaöğretim öğrencisine ölçek uygulanmıştır. Tabakalı örneklem metodu ile toplam örneklem içinde her sınıf düzeyi ve niteliklerine göre ayrılan okullar eşit seviyede ve araştırmanın evrenindeki kapladığı hacim karşılığı olarak temsil edilmiştir.

\section{Veri Toplama Araçlan}

$\mathrm{Bu}$ araştırmada uzaktan eğitim sürecinde öğrencilerin öğrenme düzeylerini belirlemek amacıyla Gülbahar (2012) tarafından hazırlanan "E-Öğrenme Sürecine İlişkin Hazırbulunuşluk ve Beklenti Düzeyi" ve "e-Öğrenme Sürecine İlişkin Memnuniyet" ölçekleri uygulanmıştır. E-Öğrenme Sürecine İlişkin Hazırbulunuşluk ve Beklenti Düzeyi ölçeğinde "Kişisel Özellikler", “Teknolojilye Erişim", “Teknik Beceriler”, "Motivasyon ve Tutum” ve "Başarı Etkileyen Faktörler" olmak üzere 5 boyut bulunmaktadır. e-Öğrenme Sürecine İlişkin Memnuniyet ölçeğinde ise "İletim ve Kulllanışl1lık", "Öğretim Süreci”, "Öğretim İçeriği" ve "Etkileşim ve Değerlendirme" olmak üzere 4 boyut bulunmaktadır. Gülbahar tarafından 26 maddelik hazırbulunuşluk ve memnuniyet ölçeği ve 29 maddelik e-öğrenme sürecine ilişkin memnuniyet ölçeğinde bulunan sorular oluşturulurken ankete katılan öğrencilerin araştırma konusu hakkında bilgi düzeylerinin yeterli olmayacağı kabul edilerek ifadelerin basit ve kolay anlaşılabilir olmasına azami dikkat edilmiştir. Ölçeğin sorularının yanıtlarında 5'li likert dereceleme yöntemi tercih edilmiştir. Buna göre; dereceleme "Hemen Hemen Hiçbir Zaman" (1), "Nadiren" (2), "Zaman zaman" (3), "Sik sık" (4) ve "Hemen hemen her zaman" (5) şeklindedir. Bu araştırmada "E-Öğrenme Sürecine İlişkin Hazırbulunuşluk ve Beklenti Ölçeği" Cronbach Alpha güvenirlik katsayısı 0,88 olarak hesaplanmıştır. "E-Öğrenme Sürecine İlişkin Memnuniyet Ölçeği”"ne ait Cronbach Alpha güvenirlik katsayısı ise 0,96 olarak hesaplanmiştır.

Ülkemizde yaşanan pandemi sürecinde verilerin toplanması için "Google Form” çevrimiçi yöntemi seçilmiştir. Okul yöneticilerinin bilgilendirilmesi üzerine sınıf rehber öğretmenleri vasıtası ile öğrenci velilerine ulaşılmıştır. Velilerin izinleri doğrultusunda öğrencilerimiz ölçeklerimi doldurarak sürece katkı sağlamıştır.

\section{Verilerin Analizi}


Bu araştırmada ilk olarak verilerin normal dağılıp dağılmadığının analiz edilmesi için basıklık ve çarpılık testi ile skewness ve kurtosis değerleri tespit edilmiştir. Bu analiz sonucu değerlerin homojen yani normal dağıldığı belirlenmiştir. Kantitatif bir parametre fikir üretebilmek için kullanılan özelliklerden biri de parametrenin sayısal ve oransal dağılımdır. Dağılım, bir parametre düzleminde belirlenen her bir koşulun ya da koşulun alt düzeylerinde gerçekleşme sıklığının özetini oluşturur (Geray, 2004: 72). Bu doğrultuda verilerin analizi sürecinde normal dağılıma sahip veriler için parametrik testler kullanılmıştır.

Tablo 1. E-Öğrenme Sürecine İlişkin Hazırbulunuşluk ve Beklenti Ölçeği ve E-Öğrenme Süreci Memnuniyet Ölçeklerine Ait Çarpıklık ve Basıklık Değerleri

\begin{tabular}{llll}
\hline & N & Çarpıklık & Basıklık \\
\hline Hazırbulunuşluk ve beklenti toplam & 389 & $-0,55$ & 0,06 \\
\hline Memnuniyet toplam & 389 & $-0,09$ & $-0,40$ \\
\hline
\end{tabular}

Her iki ölçeğe ait verilerin normal (parametrik) dağılıp dağılmadığının tespiti için çarpıklık ve basıklık değerlerinden normallikleri bakılmıştır. Skewness ve kurtosis değerleri Tablo 1'de de görüldüğ ü şekilde -1 ile +1 arasında yer almaktadır. Dolayısıyla veriler normal dağılmaktadır. Bu doğrultuda, parametrik testler yapılarak bulgular tespit edilmiştir.

Sosyal bilimlerde yapılan araştırmalarda nicel verileri analiz ederken ortalama ve standart sapma gibi başlangıç düzeyindeki betimsel değerlerin yanında en çok karşımıza çıkan teknikler, t-Testi, varyans analizi (ANOVA) ve korelasyon (bağıntı) gibi tekniklerdir. SPSS 22 istatistik uygulaması kullanılarak veriler analiz edilmiştir faydalanılmıştır. Araştırmanın belirlenen alt problemlerine yanıt verebilmek için ölçeklerden elde edilen bulgulara ait sıklık ve yüzdelik oranları ile aritmetik ortalamalar ve standart sapmalar hesaplanmıştır. Elde edilen bilgilerin araştırmanın konusu olan parametrelere göre anlamlı bir farklılık gösterip, göstermediğini tespit etmek içim t-Testi ve ANOVA testlerinden faydalanılmıştır. Araştırma için uygulanan çözümlemelerde anlamlılık düzeyi olarak 0.05 değeri kullanılmıştır.

Araştırmaya ait alt problemler için sırasıyla; 1 . ve 2. alt problemler düzey belirmeye yönelik olması nedeniyle verilere ait frekans, standart sapma, ortalama, mod, medyan gibi betimsel değerlerin analizi kullanılmıştır. Analiz sonucu elde edilen değerler Tablo 2'de yer alan sinırlar çerçevesinde yorumlanmıştır.

Tablo 2. Aritmetik Ortalama ve Düzeyleri

\begin{tabular}{ll}
\hline Aritmetik Ortalama & Düzeyi \\
\hline $1,00-1,80$ & Hiç \\
$1,81-2,60$ & Düşük \\
$2,61-3,40$ & Orta \\
$3,41-4,20$ & Yüksek \\
$4,21-5,00$ & Çok Yüksek \\
\hline
\end{tabular}

3. alt problem için iki gruba sahip demografik özellikler ilişkilerinde independent sample tTesti, üç ve daha fazla gruba sahip demografik özelliklerin ilişkilerinde one way ANOVA ve ilişkilerin ayrıntıları için ise post-hoc LSD testi analizleri kullanılmıştır. 4. alt problem değişkenler arasında anlamlı bir ilişki olup olmadığına yönelik olduğu için parametrik testlerde kullanılan pearson momentler çarpımı korelasyon analizi yapılmıştır. Son olarak 5. alt probleme cevap vermek için ise doğrusal regresyon analizi kullanılarak sonuç elde edilmesi çalışılmıştır. 


\section{Bulgular}

Araştırma verilerinin analizi ile ilk elde edilen bulgular, normallik değerleri ve kayıp veri olup olmadığına dair betimsel değer incelemeleridir. E öğrenme sürecine ilişkin hazırbulunuşluk ve beklenti ölçeğinin toplam puanı ile e öğrenme süreci memnuniyet ölçeğinin toplam puanı hesaplanarak aritmetik orta ve standart sapma değerleri hesaplanmıştır.

Tablo 3. E-Öğrenme Sürecine İlişkin Hazırbulunuşluk ve Beklenti Ölçeği ve E-Öğrenme Süreci Memnuniyet Ölçeklerinin Aritmetik Ortalama ve Standart Sapma Değerleri

\begin{tabular}{llll}
\hline & $\mathrm{N}$ & $\mathrm{X}$ & $\mathrm{Ss}$ \\
\hline Hazırbulunuşluk ve beklenti toplam & 389 & 4,00 & 0,53 \\
\hline Memnuniyet toplam & 389 & 3,49 & 0,77 \\
\hline
\end{tabular}

$\overline{\text { E-Öğrenme sürecine ilişkin hazırbulunuşluk ve beklenti ölçeği verilerinin aritmetik ortasının }}$ 4,00 olduğu tespit edilmiştir. Bu durum öğrencilerin hazırbulunuşluk ve beklenti düzeylerinin yüksek olduğunu göstermektedir. Ayrıca e öğrenme süreci memnuniyet ölçeği verilerinin aritmetik ortası ise 3,49 olarak hesaplanmıştır. Bu değer doğrultusunda memnuniyet düzeylerinin de yüksek olduğunu ortaya koymaktadır. Ölçeklere ait veriler doğrultusunda standart sapma değerleri hazırbulunuşluk ve beklenti puanlarına göre 0,53 ve memnuniyet puanlarına göre 0,77 olarak belirlenmiştir.

Araştırmanın birinci alt problemine yönelik olarak öğrencilerin uzaktan eğitim sürecine ilişkin hazırbulunuşluk düzeyinin tespiti amaçlı, “E-Öğrenme Sürecine İlişkin Hazırbulunuşluk ve Beklenti Düzeyi Ölçeğinde bulunan "Teknik Beceriler" alt boyutu ile "E-Öğrenme Sürecine İlişkin Memnuniyet Ölçeğinde bulunan "İletim ve Kullanışlılık" alt boyutunun tanımlayıcı değerleri olan frekans, aritmetik orta, standart sapma değerleri hesaplanmıştır.

Tablo 4. Teknik Beceriler ve İletim ve Kullanışlılık Alt Boyutlarına Ait Aritmetik Ortalama ve Standart Sapma Değerleri

\begin{tabular}{llll}
\hline & $\mathrm{N}$ & $\mathrm{X}$ & Ss \\
\hline Teknik beceriler toplam & 389 & 4,33 & 0,65 \\
\hline İletim ve kullanişl1lik toplam & 389 & 3,65 & 0,80 \\
\hline
\end{tabular}

Öğrencilerin uzaktan eğitim sürecine ilişkin hazırbulunuşluk düzeylerinin aritmetik ortalaması 4,33 olarak hesaplanmıştır. Bu da teknik becerilerinin çok yüksek düzeyde olduğunu göstermektedir. Diğer yandan, uzaktan eğitim süreçleri iletim ve kullanışlılık boyutu aritmetik ortalaması 3,65 olarak hesaplanmıştır. Öğrencilerin iletim ve kullanışlılık boyutunda yüksek düzeyde kullanım becerilerinin olduğu söylenebilmektedir.

Araştırmanın ikinci alt problemine yönelik olarak öğrencilerin uzaktan eğitim sürecine ilişkin beklenti düzeylerinin tespiti amaçlanmıştır. Tespit için, "E-Öğrenme Sürecine İlişkin Hazırbulunuşluk ve Beklenti Düzeyi Ölçeğinin alt boyutlarından "Motivasyon ve Tutum", "Başarıyı Etkileyen Faktörler" boyutları analiz edilmiştir. "E-Öğrenme Sürecine İlişkin Memnuniyet Ölçeği" alt boyutlarından ise "Öğretim Süreci”, "Öğretim İçeriğì" ve "Etkileşim ve Değerlendirme" boyutları analizde yer almıştır.

Tablo 5. Öğrencilerin Uzaktan Eğitim Sürecine İlişkin Beklenti Düzeyi Ölçeğinin Aritmetik Ortalama ve Standart Sapma Değerleri

$\mathrm{N} \quad \mathrm{X} \quad$ Ss




\begin{tabular}{lccc}
\hline Motivasyon ve tutum toplam & 389 & 3,45 & 0,88 \\
\hline Başarıy etkileyen faktörler toplam & 389 & 4,11 & 0,65 \\
\hline Öğretim Süreci toplam & 389 & 3,41 & 0,88 \\
\hline Öğretim İçeriği toplam & 389 & 3,70 & 0,89 \\
\hline Etkileşim ve değerlendirme toplam & 389 & 3,36 & 0,91 \\
\hline
\end{tabular}

Tablo 5'te yer alan analiz sonuçları incelendiğinde, "başarıyı etkileyen faktörler" alt boyutuna ait aritmetik ortalamanın, diğer alt boyutlar arasında, 4,11 ile en yüksek düzeye sahip olduğu görülmüsşür. "Motivasyon ve tutum" boyutu 3,45, "Öğretim süreci" boyutu 3,41, "Öğretim içeriği" boyutu 3,70 ve "Etkileşim ve değerlendirme" boyutu 3,36 ile orta düzeye sahip olmuşlardır.

Araştırmanın üçüncü alt problemine yönelik olarak öğrencilerin uzaktan eğitim sürecine ilişkin hazırbulunuşluk ve beklenti düzeyleriyle, sürece ilişkin memnuniyetlerinin öğrencilerin demografik özelliklerine göre ilişkileri için parametrik testlerden t-testi ve anova analizleri yapılmıştır. Cinsiyet gibi iki gruba sahip belirli değişkenler için t-testi uygulanırken, üç ve daha fazla gruba sahip öğrencilerin sınıf düzeyi ve eğitim gördükleri okul tipleri için one way anova testi uygulanmıştır. Bu şekilde belirli bir değişkene bağlı olarak farklılık sergileyip sergilemediğinin tespiti sağlanmıştır.

Tablo 6. Öğrencilerin Cinsiyetlerine Göre Uzaktan Eğitim Sürecine İlişkin Hazırbulunuşluk ve Beklentileri ve Uzaktan Eğitim Sürecine İlişkin Memnuniyet Puanlarına Uygulanan Bağımsız Grup t-Testi Sonuçları

\begin{tabular}{llllllll}
\hline & Cinsiyet & $\mathrm{N}$ & $\mathrm{X}$ & $\mathrm{SD}$ & $\mathrm{t}$ & $\mathrm{df}$ & $\mathrm{p}$ \\
\hline Hazırbulunuşluk & K1z & 228 & 3,9789 &, 53720 & \multirow{2}{*}{1,119} & \multirow{2}{*}{387} & \multirow{2}{*}{, 750} \\
ve beklenti & Erkek & 161 & 4,0401 &, 52370 & & & \multirow{2}{*}{, 547} \\
\hline \multirow{2}{*}{ Memnuniyet } & K1z & 228 & 3,4643 &, 76006 & \multirow{2}{*}{0,824} & \multirow{2}{*}{387} & \multirow{2}{*}{, 79059} \\
& Erkek & 161 & 3,5299 & & & \\
\hline
\end{tabular}

Öğrencilerin, uzaktan eğitim sürecine ilişkin hazırbulunuşluk ve beklenti düzeyleriyle uzaktan eğitim sürecine ilişkin memnuniyet algılarında cinsiyete göre anlamlı bir farklılığa sahip olup olmadığının tespiti için t-testi yapılmıştır. Tablo 5 'te yer alan analiz sonuçları doğrultusunda öğrencilerin hazırbulunuşluk ve beklentilerinde cinsiyetlere göre aritmetik orta arasındaki fark incelendiğinde ( $\mathrm{t}=1.119 ; \mathrm{p}=.750>.05)$ istatiksel olarak anlamlı bir farklılık olmadığı tespit edilmiştir. Varyansların homojen olduğu ve öğrencilerin cinsiyetlerine göre hazırbulunuşluk ve beklenti düzeylerinde farklılık görülmemektedir. Benzer şekilde öğrencilerin uzaktan eğitim süreçlerinden memnuniyetleri cinsiyetlerine göre ele alındığında $(\mathrm{t}=0.824 ; \mathrm{p}=.547>.05)$ istatiksel olarak anlamlı bir farklılık görülmemektedir. Bu bulgu kız ve erkek öğrenciler için uzaktan eğitim süreçlerine ilişkin hazırbulunuşluk ve beklenti ile memnuniyet düzeyleri yakın ölçülerde seyretmekte şeklinde ifade edilebilir.

Tablo 7. Öğrencilerin Uzaktan Eğitim Sürecine İlişkin Hazırbulunuşluk ve Beklentileriyle Uzaktan Ĕgitim Sürecine İlişkin Memnuniyetlerinin Okul Türüne Göre Farklılaşıp Farklılaşmadığını Belirlemek İçin Yapılan Tek Yönlü Varyans Analizi (ANOVA) Sonuçları

\begin{tabular}{|c|c|c|c|c|c|c|c|c|c|c|}
\hline & \multicolumn{3}{|c|}{$\mathrm{f}, \mathrm{X}$ ve $S$ değerleri } & \multicolumn{7}{|c|}{ ANOVA sonuçları } \\
\hline & Okul Türü & $\mathrm{N}$ & $x$ & SD & Kaynak & KT & $\mathrm{df}$ & $\mathrm{KO}$ & $\mathrm{F}$ & $\mathrm{P}$ \\
\hline \multirow{3}{*}{$\begin{array}{l}\text { Hazırbulunuş } \\
\text { luk ve } \\
\text { beklenti }\end{array}$} & Fen Lisesi & 26 & 4,1864 & ,374 & G.Aras1 & 2,690 & 4 & 672 & & \\
\hline & $\begin{array}{l}\text { Sinavsiz } \\
\text { AL }\end{array}$ & 154 & 3,9830 &, 523 & G.İçi & 107,056 & 384 & ,279 & 2,412 & , 049 \\
\hline & Sinavlı AL & 18 & 4,2564 & 401 & Toplam & 109,746 & 388 & & & \\
\hline
\end{tabular}




\begin{tabular}{llcccccccccc}
\hline & Meslek L & 135 & 3,9425 &, 588 & & & & & & \\
& AïHL & 56 & 4,0460 &, 480 & & & & & & \\
& Toplam & 389 & 4,0043 &, 532 & & & & & & \\
\hline \multirow{4}{*}{ Memnuniyet } & Fen Lisesi & 26 & 3,6883 &, 668 & G.Arasi & 5,107 & 4 & 1,277 & & \\
& Sinavsız & 154 & 3,3639 &, 766 & G.İcii & 226,438 & 384 &, 590 & 2,165 &, 072 \\
& AL & & & & & & & & & \\
& Sinavlı AL & 18 & 3,5766 &, 717 & Toplam & 231,545 & 388 & & & \\
& Meslek L & 135 & 3,5949 &, 754 & & & & & & \\
& AìHL & 56 & 3,4741 &, 860 & & & & & & \\
& Toplam & 389 & 3,4914 &, 773 & & & & & & \\
\hline
\end{tabular}

Öğrencilerin uzaktan eğitim sürecine ilişkin hazırbulunuşluk ve beklenti düzeyleriyle memnuniyet düzeylerinin eğitim gördükleri okul türlerine göre anlamlı bir farklılı̆̆ın olup olmadığının incelenmesi için ANOVA (tek yönlü varyans) analizi uygulanmıştır. Okul tiplerine göre istatiksel olarak hazırbulunuşluk ve beklenti düzeylerinde ( $\mathrm{F}=2.412 ; \mathrm{p}=.049<.05)$ anlamlı bir farklılık olduğu tespit edilmiştir. Ancak aynı durum memnuniyet düzeylerine göre tespit edilememiştir. E öğrenme sürecine ilişkin memnuniyet düzeyleri, öğrencilerin eğitim aldıkları okul türüne göre istatiksel olarak ( $\mathrm{F}=2.165 ; \mathrm{p}=.072>.05)$ anlamlı bir farklılık göstermemektedir.

Okul türlerine göre hazırbulunuşluk ve beklenti düzeylerinde anlamlı farklılığın hangi okul türlerinden kaynaklandığının ayrıntılı tespiti için post-hoc LSD analizi uygulanmıştır.

Tablo 8. Öğrencilerin Uzaktan Eğitim Sürecine İlişskin Hazırbulunuşluk ve Beklentilerinin Okul Türüne Göre Farklılaşıp Farklılaşmadığını Belirlemek İçin Yapılan Tek Yönlü Varyans Analizi (ANOVA) Sonrası Post-Hoc LSD Testi Sonuçları

\begin{tabular}{|c|c|c|c|c|c|}
\hline & Okul Türü (i) & Okul Türü (j) & $\mathbf{i}-\mathbf{j}$ & Std. & p \\
\hline \multirow{20}{*}{$\begin{array}{l}\text { Hazırbulunuş } \\
\text { luk ve beklenti }\end{array}$} & Fen Lisesi & Sinavsız AL & 20337 & 11195 & , 070 \\
\hline & & Sinavlı AL &,- 07002 & 16190 & 666 \\
\hline & & Meslek L & ,24394* & 11308 & 032 \\
\hline & & AİHL & 14037 & ,12530 & ,263 \\
\hline & Sinavsız AL & Fen Lisesi & -20337 & 11195, & 070 \\
\hline & & Sinavlı AL & -,27339* & 13152 & 038 \\
\hline & & Meslek L & ,04057 & ,06225 & ,515 \\
\hline & & AİHL &,- 06300 & ,08239 & , 445 \\
\hline & Sinavlı AL & Fen Lisesi & 07002 & 16190 & 666 \\
\hline & & Sinavsiz AL & ,27339* & 13152 & ,038 \\
\hline & & Meslek L & ,31396* & 13249 & ,018 \\
\hline & & AİHL & 21039 & ,14306 & ,142 \\
\hline & Meslek L & Fen Lisesi &,$- 24394^{*}$ & 11308 & ,032 \\
\hline & & Sinavsiz AL &,- 04057 & ,06225 & ,515 \\
\hline & & Sinavlı AL &,$- 31396^{*}$ & 13249 & ,018 \\
\hline & & AİHL &,- 10357 & ,08393 & ,218 \\
\hline & AİHL & Fen Lisesi &,- 14037 & , 12530 & ,263 \\
\hline & & Sinavsiz AL &, 06300 & ,08239 & ,445 \\
\hline & & Sinavlı AL &,- 21039 & 14306 & 142 \\
\hline & & Meslek L & 10357 & 08393 & 218 \\
\hline
\end{tabular}


Uzaktan eğitim sürecine ilişkin hazırbulunuşluk ve beklenti puanları doğrultusunda alt gruplar arasındaki farklılığın tespiti için yapılan tek yönlü varyans (ANOVA) analizinin ardından yapılan post-hoc LSD testi sonuçlarına göre Fen Liselerinde eğitimlerine devam eden öğrenciler ile Meslek Liselerinde eğitimlerine devam eden öğrenciler arasında Fen Liselerinde eğitim alanlar lehine $\mathrm{p}=.032<.05$ düzeyinde, hazırbulunuşluk ve beklenti düzeylerinde anlamlı farklılık tespit edilmiştir. Buna göre Fen Liselerinde eğitimlerine devam eden öğrencilerin hazırbulunuşluk ve beklenti düzeylerinin ( $X=4.1864)$, Meslek Liselerinde eğitimlerine devam eden öğrencilerin hazırbulunuşluk ve beklenti düzeylerinden $(X=3.9425)$ fazla olduğu belirlenmiştir.

Post-hoc LSD testi sonuçlarına göre sınavla öğrenci alan Anadolu Liselerinde eğitimlerine devam eden öğrenciler ile sınavsız öğrenci alan Anadolu Liselerinde eğitimlerine devam eden öğrenciler arasında sınavla öğrenci alan Anadolu Liselerinde eğitim alanlar lehine $p=.038<.05$ düzeyinde, hazırbulunuşluk ve beklenti düzeylerinde anlamlı farklılık tespit edilmiştir. Ayrıca sinavla öğrenci alan Anadolu Liselerinde eğitimlerine devam eden öğrenciler ile Meslek Liselerinde eğitimlerine devam eden öğrenciler arasında sınavla öğrenci alan Anadolu Liselerinde eğitim alanlar lehine $\mathrm{p}=.018<.05$ düzeyinde, hazırbulunuşluk ve beklenti düzeylerinde anlamlı farklılık tespit edilmiştir. Buna göre sinavla öğrenci alan Anadolu Liselerinde eğitimlerine devam eden öğrencilerin hazırbulunuşluk ve beklenti düzeylerinin $(X=4.2564)$, hem sinavsız öğrenci alan Anadolu Liselerinde eğitimlerine devam eden öğrencilerin hazırbulunuşluk ve beklenti düzeylerinden ( $X=3.9830)$ hem de Meslek Liselerinde eğitimlerine devam eden öğrencilerin hazırbulunuşluk ve beklenti düzeylerinden $(X=3.9425)$ fazla olduğu belirlenmiştir.

Araştırmanın dördüncü alt problemine yönelik olarak öğrencilerin uzaktan eğitim sürecine ilişkin hazırbulunuşluk ve beklenti düzeyleriyle memnuniyetleri arasındaki ilişkinin varlığının irdelenmesi için pearson momentler çarpımı korelasyon analizi yapılmıştır.

Tablo 9. Uzaktan Eğitim Sürecine İlişkin Hazırbulunuşluk ve Beklenti Düzeyleriyle Uzaktan Eğitim Sürecine İlişkin Memnuniyet Arasındaki Korelasyon Analizi Sonuçları

\begin{tabular}{lcccccc}
\hline & $\begin{array}{c}\text { Kişisel } \\
\text { Özellikler }\end{array}$ & $\begin{array}{c}\text { Teknolojiye } \\
\text { Erişim }\end{array}$ & $\begin{array}{c}\text { Teknik } \\
\text { Beceriler }\end{array}$ & $\begin{array}{c}\text { Motivasyon } \\
\text { ve Tutum }\end{array}$ & $\begin{array}{c}\text { Başarıyı } \\
\text { Etkileyen } \\
\text { Faktörler }\end{array}$ & $\begin{array}{c}\text { Hazırbulunuşluk } \\
\text { ve Beklenti }\end{array}$ \\
\hline $\begin{array}{l}\text { İletişim ve } \\
\text { Kullanişlılık }\end{array}$ &, $464^{* *}$ &, $284^{* *}$ &, $249^{* *}$ &, $507^{* *}$ &, $455^{* *}$ &, $296^{* *}$ \\
\hline Öğretim Süreci &, $308^{* *}$ &, $192^{* *}$ &, $139^{* *}$ &, $467^{* *}$ &, $376^{* *}$ &, $328^{* *}$ \\
\hline Öğretim İçeriği &, $397^{* *}$ &, $231^{* *}$ &, $162^{* *}$ &, $483^{* *}$ &, $369^{* *}$ &, $366^{* *}$ \\
\hline $\begin{array}{l}\text { Etkileşim ve } \\
\text { Değgerlendirme }\end{array}$ &, $331^{* *}$ &, $210^{* *}$ &, $219^{* *}$ &, $406^{* *}$ & &, $392^{* *}$ \\
\hline Memnuniyet &, $375^{* *}$ &, $229^{* *}$ &, $192^{* *}$ &, $466^{* *}$ &, $300^{* *}$ \\
\hline
\end{tabular}

Tablo 9'da görüldüğü üzere öğrencilerin uzaktan eğitim sürecine ilişkin hazırbulunuşluk ve beklenti düzeyleriyle memnuniyetleri arasındaki ilişkinin varlığının irdelenmesi için yapılan pearson momentler çarpımı korelasyon analizi sonuçlarına göre pozitif yönde orta düzeyde ilişkili oldukları bulgusu elde edilmiştir. Her iki ölçeğin tüm alt boyutlarının ve ölçeklere ait toplam puanlarının karşılaştırıldığı Tablo 10' da r=.500 değeriyle hazırbulunuşluk ve beklenti ölçeğinin alt boyutlarından motivasyon ve tutum ile memnuniyet ölçeğinin alt boyutlarında iletim ve kullanışlılık arasında en yüksek değerde ilişkililik olduğu tespit edilmiştir. Alt boyutlarda en düşük düzeyde ilişkililiğin r=.139 ile teknik beceriler ve öğretim süreci arasında 
olduğu görülmektedir. Ölçeklere ait toplam puanlar arasındaki ilişkililik ise $r=.500$ değerindedir.

Araştırmanın beşinci alt problemine yönelik olarak, öğrencilerin uzaktan eğitim sürecine ilişkin hazırbulunuşluk ve beklenti düzeylerinin, memnuniyetlerini yordamasına ilişkin doğrusal regresyon analizi yapılmıştır.

Tablo 10. Öğrencilerin Uzaktan Eğitim Sürecine İlişkin Hazırbulunuşluk Düzeylerinin Uzaktan Eğitim Sürecine İlişkin Memnuniyetlerini Yordamasına İlişkin Regresyon Analizi Sonuçları

\begin{tabular}{llcccccccc}
\hline $\begin{array}{l}\text { Bağımsız } \\
\text { Değişken }\end{array}$ & $\begin{array}{l}\text { Bağımlı } \\
\text { Değişken }\end{array}$ & $\mathbf{B}$ & $\begin{array}{l}\text { Std. } \\
\text { Hata }\end{array}$ & $\mathbf{(} \boldsymbol{\beta})$ & $\mathbf{t}$ & $\mathbf{R}$ & $\mathbf{R}^{2}$ & $\mathbf{F}$ & $\boldsymbol{p}$ \\
\hline $\begin{array}{l}\text { Hazırbulunuş- } \\
\text { luk düzeyi }\end{array}$ & Memnuniyet &, 344 &, 030 &, 500 & 11,349 &, 500 &, 250 & 128,800 &, 000 \\
\hline
\end{tabular}

Tablo $10^{\prime}$ da, yer alan analiz sonuçları doğrultusunda, öğrencilerin uzaktan eğitim sürecine ilişkin hazırbulunuşluk ve beklenti düzeylerinin, memnuniyetlerini yordamasına ilişkin doğrusal regresyon analizi görülmektedir. Bu doğrultuda, modelin \%25'nin (R2=.250) açıklanabilir olduğu bulgusu ortaya çıkmıştır. $p=.000<.05$ değeriyle modelin anlamlı olduğu anlaşılmaktadır. Öğrencilerin uzaktan eğitim sürecine ilişkin hazırbulunuşluk ve beklenti düzeylerinin, memnuniyetleri üzerinde anlamlı bir ilişkisinin varlığı söz konusudur. Öğrencilerin hazırbulunuşluk ve beklenti düzeylerindeki bir birimlik artış memnuniyetlerinde $0.344^{\prime} l u ̈ k$ bir artışa sebep olmaktadır.

\section{Sonuç, Tartışma Ve Öneriler}

Ortaöğretim öğrencilerinin uzaktan eğitim süreçlerine ilişkin hazırbulunuşluk boyutlarından teknik beceriler düzeylerinin çok yüksek olduğu görülmüştür. Benzer şekilde Başaran ve diğerleri (2020) Covid-19 salgını sürecinde 21. yüzyıl öğrencilerinin sahip olduğu bilişim ve teknik deneyimlerinin uzaktan eğitim süreçlerine adaptasyonlarını hızlandırdığını ortaya koymuşlardır. Başaran ve diğerlerine (2020) göre çağ öğrencileri bilgi ve iletişim teknolojilerine hâkimler ve bu durum uzaktan eğitime geçişte teknik anlamda öğrencilere kolaylık sağlamıştır. Bu sonuçtan farklı olarak ise Can (2020) öğrencilerin teknik becerilerinin yüksek olmasına karşın uzaktan eğitim süreçlerine adaptasyonda sorun yaşadıklarını ortaya koymuştur. Can’a (2020) göre öğrenciler bilgi ve iletişim teknolojilerine ne kadar hâkimseler de uzaktan eğitime uygun davranışlar geliştirmeleri zaman almaktadır. Yani teknik becerilerinin yüksek olması uzaktan eğitim süreçlerine hazırbulunuşluk düzeylerinin yüksek olmasını sağlamamaktadır.

Bulgular doğrultusunda elde edilen bir diğer sonuca göre ise ortaöğretim öğrencilerinin uzaktan eğitim süreçlerine ilişkin hazırbulunuşluk boyutlarından iletim ve kullanışlılıkta yüksek düzeyde becerilere sahip oldukları görülmektedir. Bu sonuca benzer şekilde Yadigar (2010) ise bu sonucun aksine yeni neslin içinde yaşadığı çağ nedeniyle uzaktan eğitim süreçlerinde yer alan bilgi ve iletişim teknolojilerine hakimiyetlerinin yüksek olduğunu sonucuna ulaşmıştır. Bu nedenle öğrencilerin kullanışlılık boyutunda yüksek düzeyde kullanım becerilerinin varlığını ortaya koymuştur. Clark (2020) ise çalışması sonucu, öğrencilerin bilişim teknolojilerini kullanırken iletim ve kullanışlılık boyutlarında yeterliliklerinin beklenenin altında olduğunu belirtmiştir.

Araştırmanın ikinci amacı doğrultusunda öğrencilerin uzaktan eğitim süreçlerine ilişkin beklenti düzeylerinin başarıyı etkileyen faktörler boyutunda yüksek olduğu sonucuna ulaşılmıştır. Bunun yanı sıra motivasyon ve tutum, öğretim süreci, öğretim içeriği ve etkileşim 
ve değerlendirme boyutlarında beklentilerinin orta düzeyde olduğu tespit edilmiştir. Bu sonuç ortaöğretim öğrencilerinin uzaktan eğitim süreçlerinden başarı etkileyen faktörler anlaminda beklentilerinin yüksek olduğu ancak motivasyon, öğretim süreci ve içeriği ve etkileşim ve değerlendirme beklentilerinin ise ortalama değerlerde olduğu görülmektedir. $\mathrm{Bu}$ sonuçla paralel şekilde Valentiner (2002) eğitim süreci uzaktan da yürütülse öğrencilerin başarı konusunda yüksek beklentilere sahip oldukları sonucuna ulaşmıştır. Yine benzer şekilde Demir ve Özdaş (2020) öğretmen görüşlerini aldıkları çalışmalarında öğrenci ve velilerin uzaktan eğitimde başarı beklentisinin yüz yüze eğitimden farklı olmayarak yüksek düzeyde olduğunu ortaya koymuşlardır. Bu sonuçların aksine Antalyalı (2004) uzaktan eğitim sürecinin öğrenciler yüz yüze eğitim kadar dikkatli takip edilmediği dolaysıyla bir başarı beklentilerinin olmadığı sonucuna ulaşmıştır.

$\mathrm{Bu}$ araştırmanın üçüncü amacı doğrultusunda öğrencilerin uzaktan eğitim süreçlerine ilişki hazırbulunuşluk ve beklentilerinde cinsiyetlerine göre anlamlı bir farklılık olmadığı sonucuna ulaşılmıştır. Benzer şekilde öğrencilerin uzaktan eğitim süreçlerine ilişkin memnuniyetlerinde cinsiyetlerine göre anlamlı bir farklılık görülmemektedir. Bu durumda kız ve erkek öğrenciler için uzaktan eğitim süreçlerine ilişkin hazırbulunuşluk ve beklenti ile memnuniyet düzeyleri yakın ölçülerde olduğu sonucuna varılmıştır. Bu sonucun aksine Akdemir ve Kılıç (2020) yükseköğretimde kız öğrencilerin uzaktan eğitim süreçlerine ilişkin hazırbulunuşluk ve beklentilerinin erkek öğrencilerden fazla olduğu sonucunu ortaya koymuşlardır.

Bir diğer bulguya göre öğrencilerin uzaktan eğitim sürecine ilişkin hazırbulunuşluk ve beklenti düzeyleriyle uzaktan eğitim sürecine ilişkin memnuniyetlerinin sinıf düzeylerine göre anlamlı bir farklılık olmadığı sonucuna ulaşılmıştır. Ancak A ğır (2007) ilköğretim öğretmenleriyle yürüttüğü çalışmasında daha küçük sınıfların üst sınıflara göre uzaktan eğitim süreçlerinden beklenti ve memnuniyetlerinin daha yüksek olduğu sonucunu ortaya koymuştur. Aktay ve Keskin (2020) benzer olarak gerek EBA platformuna ilgi konusunda küçük yaş gruplarındaki öğrencilerin ilgilerinin çok daha yüksek olduğunu tespit etmişlerdir.

Öğrencilerin uzaktan eğitim sürecine ilişkin hazırbulunuşluk ve beklenti düzeylerinin okul türlerine göre anlamlı bir farklılık gösterdiği sonucuna ulaşılırken memnuniyet düzeylerinin eğitim gördükleri okul türlerine göre anlamlı bir farklılık göstermediği tespit edilmiştir. Fen Liselerinde eğitimlerine devam eden öğrencilerin uzaktan eğitim sürecine ilişkin hazırbulunuşluk ve beklenti düzeylerinin Meslek Liselerinde eğitimlerine devam eden öğrencilere göre fazla olduğu sonucuna ulaşılmıştır. Ayrıca sınavla öğrenci alan Anadolu Liselerinde eğitimlerine devam eden öğrencilerin uzaktan eğitim sürecine ilişkin hazırbulunşluk ve beklenti düzeylerinin sinavsız öğrenci alan Anadolu Liseleri ve Meslek Liselerinde eğitimlerine devam eden öğrencilere göre yüksek olduğu tespit edilmiştir. Bu sonuçlara benzer şekilde Emin (2020) Meslek Liselerinde eğitimlerine devam eden öğrencilerin diğer liselerde eğitimlerine devam eden öğrencilere göre uzaktan eğitime katılımlarının çok daha az olduğunu ortaya koymuştur. Bunu da uzaktan eğitim süreçlerinden beklenti düzeylerinin düşük olmasına dayandırmıştır.

Araştırmanın dördüncü amacı doğrultusunda öğrencilerin uzaktan eğitim sürecine ilişkin hazırbulunuşluk ve beklenti düzeyleriyle memnuniyetleri arasında pozitif yönde orta düzeyde anlamlı bir ilişki olduğu tespit edilmiştir. Bu sonuca göre öğrencilerin uzaktan eğitim süreçlerine hazırbulunuşluk ve beklenti düzeyleri yüksekse memnuniyetleri de yüksek olmaktadır. Bu sonuçla paralel olarak Erdemir (2014) uzaktan eğitim süreçlerinin etkililiğiyle ilgili yürüttüğü çalışma doğrultusunda öğrencilerin uzaktan eğitimden arzuladığı sonucu 
almasının ve durumdan memnun olmasının süreç öncesi hazırbulunuşluk düzeyiyle ilişkili olduğunu ortaya koymuştur. Esgice (2015) ise bunun hazırbulunuşlukla ilişkili olmadığı, tamamen uzaktan eğitim sürecinin öğrenciye hitap etmesiyle ilişkili olduğu sonucuna ulaşmıştır.

Son olarak ise öğrencilerin uzaktan eğitim sürecine ilişkin hazırbulunuşluk ve beklenti düzeylerinin, memnuniyetlerini yordadığı sonucuna ulaşılmıştır. Bu doğrultuda öğrencilerin uzaktan eğitim sürecine ilişkin hazırbulunuşluk ve beklenti düzeylerinin, memnuniyetleri üzerinde anlamlı bir ilişkisinin varlığı söz konusudur. Yani öğrencilerin hazırbulunuşluk ve beklenti düzeylerinde artış oldukça memnuniyet düzeyleri de artmaktadır. Telli ve Altun (2020) uzaktan eğitime hazırbulunuşluk ve adaptasyonda ne kadar iyileşme olursa uzaktan eğitimden alınan doyum ve memnuniyetin o kadar iyileşeceğini ortaya koymuşlardır. Benzer şekilde Özbay (2015) uzaktan eğitim süreçlerine hazırbulunuşluk ve memnuniyet düzeylerinin paralel olarak artıp azaldığını belirtmiştir. Dündar ve diğerleri (2017) ise bu sonuçların aksine memnuniyet düzeyinin sadece süreç içi faaliyetlerle artacağını veya azalacağını ifade etmişlerdir.

Bu araştırma İstanbul ili Maltepe ilçesi bulunan devlet ortaöğretim kurumlarında eğitim gören öğrencilerle sınırlıdır. Ayrıca araştırma katılımcıların ölçeklere verdikleri cevaplar ile sinirlidir.

Araştırmada ortaöğretim öğrencilerinin uzaktan eğitim süreçlerine ilişkin hazırbulunuşluk boyutlarından teknik beceriler düzeylerinin yüksek olduğu tespit edilmiştir. Bu sonuç doğrultusunda teknik becerileri yüksek olan öğrencilerin uzaktan eğitim süreçlerinde aktif katılım ve olumlu performans göstermelerinin gerekliliği düşünülmektedir. Bu açıdan öğrencileri teknik becerilerini fayda yönünde kullanmaya yönlendirmek önem arz etmektedir. Bunun için okul rehberlik servisleri desteğiyle velilerle işbirliği yapılarak öğrencilerin uzaktan eğitim sürecine yönelik motivasyonları arttırılabilir.

Ortaöğretim öğrencilerinin uzaktan eğitim süreçlerine ilişkin hazırbulunuşluk boyutlarından iletim ve kullanışlılıkta orta düzeyde becerilere sahip oldukları tespit edilmiştir. Bu sonuç, sahip oldukları teknik becerileri iletim ve kullanışlılık boyutlarına aktaramadıklarını düşündürmektedir. Bu bağlamda öğrencilere çevrimiçi platformları kullanma beceri ve yeterliklerini geliştirecek uygulamalı eğitimler verilebilir. Bu eğitimler öğrencilerin aktif oldukları platformlarda daha bilinçli ve kendilerini koruyan davranışlar sergilemelerini sağlayabilir.

Öğrencilerin uzaktan eğitim süreçlerine ilişkin beklenti düzeylerinin başarıyı etkileyen faktörler boyutunda yüksek olduğu tespit edilmiştir. Bu sonuç ister yüz yüze eğitimde isterse uzaktan eğitimde öğrencilerin başarılı olmak istediklerini düşündürmektedir. Bu istekliliğin devamı ve karşılığının alınmasın için uzaktan eğitim süreçlerinin başarı odaklı olarak yürütülmesine dikkat çekilebilir. Burada da eğitimci ve öğretmenlere sorumluluklar düşmektedir. Eğitimci ve öğretmenler uzaktan eğitim süreçlerinde başarıyı yükseltecek faaliyetler konusunda eğitim alabilirler. Bu eğitimler bireysel farklılıklar taşıyan öğrenciler için çeşitli öğrenme etkinlikleri sunmalarını sağlayabileceği gibi yönlendirme yeterliliklerinin artmasina da neden olabilir.

Öğrencilerin uzaktan eğitim süreçlerine ilişkin beklenti düzeylerinin motivasyon ve tutum, öğretim süreci, öğretim içeriği ve etkileşim ve değerlendirme boyutlarında beklentilerinin orta düzeyde olduğu tespit edilmiştir. Bu tespit öğrencilerin süreçle ilgili derinlemesine bilgi sahibi 
olmadıklarını düşündürmektedir. Uzaktan eğitim sürecine ilişkin kendileri için doğru ve uygun beklentilere sahip olmaları amacıyla süreç her yönüyle öğrencilere tanıtılabilir. Süreç hakkında yeterli bilgi sahibi olan öğrenciler kendi süreçlerini kendileri şekillendirebilir.

Öğrencilerin uzaktan eğitim sürecine ilişkin hazırbulunuşluk ve beklenti düzeylerinin okul türlerine göre anlamlı bir farklılık gösterdiği sonucuna ulaşılırken memnuniyet düzeylerinin eğitim gördükleri okul türlerine göre anlamlı bir farklılık göstermediği tespit edilmiştir. Anlamlı farklılığın özellikle Fen Liselerinde eğitim gören öğrenciler lehine olduğu tespit edilmiştir. Bu öğrenciler belirli bir başarı seviyesi olan öğrencilerin sınavla seçilmesiyle Fen Liselerinde eğitim almaktadırlar. Ancak bu durum başarısı zaten düşük veya belirli bir alt seviyede olan öğrencilerin uzaktan eğitim süreçlerinde daha da eğitim ortamlarından koptuklarını düşündürmektedir. Bu noktada en çok eğitimden kopmaların Meslek Liselerinde eğitim gören öğrencilerde olduğu söylenebilir. Meslek Liseleri öğrencilerine yönelik uzaktan eğitim süreçlerinde destekleme faaliyetleri sürdürülebilir. Öğrencileri motive edecek ve eşit imkânlar sağlayacak faaliyetler için çeşitli kurum veya kuruluşlardan destek alınabilir. Velilerinin bilgilendirilmesi için Meslek Liselerine has veli eğitim çalışmaları gerçekleştirilebilir. Tüm bunlar Meslek Liseleri öğrencilerinin uzaktan eğitim süreçlerine düzenli olarak katılımlarını sağlayabilir.

Öğrencilerin uzaktan eğitim sürecine ilişkin hazırbulunuşluk ve beklenti düzeyleriyle memnuniyetleri arasında pozitif yönde orta düzeyde anlamlı bir ilişki olduğu tespit edilmiştir. Teknolojik bilgilere sahip olmanın artık her alanda gerekli olduğu düşünülmektedir. Eğitim ise bu alanların başında gelmektedir. Özellikle COVID-19 salgın süreciyle birlikte eğitimde teknoloji odaklı süreçlere hızlı bir geçiş söz konusu olmuştur. Bu konuda öğrencilerin sürece hazırbulunuşluk düzeylerinin yüksek tutulması paralelinde süreçten başarı elde etmelerinin ve memnun olmalarının da yüksek olmasını sağlayabilir.

Öğrencilerin uzaktan eğitim sürecine ilişkin hazırbulunuşluk ve beklenti düzeylerinin, memnuniyetlerini yordadığı sonucuna ulaşılmıştır. Bu durum öğrencilerin hazırbulunuşluk ve beklenti düzeyleri arttıkça memnuniyet düzeylerinin de artmasına neden olduğunu göstermektedir. Öğrencilerin hazırbulunuşluk düzeylerinin yüksek hale getirilmesinin uzaktan eğitimden başarı elde edeceklerini düşündürmektedir. Bu bağlamda uzaktan eğitime hazırlık niteliğinde uygulama ve faaliyetler sunulması öğrencilerin süreçteki başarılarının artmasını sağlayabilir. Başarı elde eden öğrencinin ise motivasyon ve memnuniyet düzeyinin yüksek olmasına neden olabilir.

\section{Katkı Oranı Beyanı}

Bu çalışmaya birinci yazar \%60 oranında ikinci yazar \%40 oranında katkı sağlamıştır.

\section{Çatışma Beyanı}

Bu çalışmada herhangi bir potansiyel çıkar çatışması bulunmamaktadır.

\section{KAYNAKÇA}

Ağır, F. (2007). Özel okullarda ve devlet okullarında çalışan ilköğretim öğretmenlerinin uzaktan eğitime karşı tutumlarının belirlenmesi, (Yüksek Lisans Tezi). Balıkesir Üniversitesi, Fen Bilimleri Enstitüsü, Balıkesir. 
Ak, A., Oral, B. ve Topuz, V. (2018). Marmara Üniversitesi Teknik Bilimler Meslek Yüksekokulu uzaktan öğretim sürecinin değerlendirilmesi. Bilim Eğitim Sanat ve Teknoloji Dergisi, 2(1), 73-80.

Akdemïr, A. ve Kılıç, A. (2020). Yükseköğretim öğrencilerinin uzaktan eğitim uygulamalarına bakışının belirlenmesi. Milli Eğitim Dergisi, 49(1), 685-712 .

Aker, M. B. (2002). Hipermedya destekli uzaktan eğitimi, (Doktora Tezi). Gazi Üniversitesi, Fen Bilimleri Enstitüsü, Ankara.

Aktay, S. ve Keskin, T. (2020). Eğitim Bilişim A $\breve{g} 1$ (EBA) incelemesi. Eğitim Kuram ve Uygulama Araştırmaları Dergisi, 2(3), 27-44.

Altuncı, Y. T., Salman, C. ve Doğan, Z. M. (2009). Mesleki eğitim sorunları ve yeni model arayışları. I. İnşaat Mühendisliği Eğitim Sempozyumu, Antalya, Türkiye.

Antalyalı, Ö. L. (2004). Uzaktan eğitim algısı ve yöneylem araştırması dersinin uzaktan eğitim ile verilebilirliği, (Yüksek Lisans Tezi). Süleyman Demirel Üniversitesi, Sosyal Bilimler Enstitüsü, Isparta.

Başaran, M., Doğan, E., Karaoğlu, E. ve Şahin, E. (2020). Koronavirüs (Covid-19) pandemi sürecinin getirisi olan uzaktan eğitimin etkililiği üzerine bir çalışma. Academia Eğitim Araştırmaları Dergisi, 5(2), 368-397.

Berg, G. ve Simonson, B. (2016). Distance education. Encyclopædia Britannica https://www.britannica.com/topic/distance-learning adresinden erişilmiştir.

Bolliger, D. U. ve Martin, F. (2018). Instructor and student perceptions of online student engagement strategies. Distance Educaiton, 39(4), 568-583.

Can, E. (2020). Coronavirüs (Covid-19) pandemisi ve pedagojik yansımaları: Türkiye'de açık ve uzaktan eğitim uygulamaları. Türkiye'de Açık ve Uzaktan Ĕ̆itim Uygulamaları, 6(2), 11-53.

Clark, J. T. (2020). Distance education. E. Iadanza (Ed.), Clinical engineering handbook içinde (410-415. ss.). Cambridge: Academic Press.

Cookson, P. S. (1989). Research on learners and learning in distance education. The American Journal of Distance Education, 2(1), 22-34.

Cowles, D. (1989). Consumer perceptions of interactive media. Journal of Broadcasting and Electronic Media, 33, 83-89. 
Curabay, Ş. ve Demiray, E. (2002). 20. Kuruluş yılında Anadolu Üniversitesi Açıköğretim Sistemi ve Açıöğgretim Fakültesi Ĕ̆gitim Televizyonu (ETV). Eskişehir: Anadolu Üniversitesi Yayınları.

Çoban, S. (2013). Uzaktan ve teknoloji destekli eğitimin gelişimi. XVI. Türkiye'de İnternet Konferansı Bildiri Kitabı, İstanbul.

Dikmen, S. ve Bahçecï, F. (2020). Covid-19 pandemisi sürecinde yükseköğretim kurumlarının uzaktan eğitime yönelik stratejileri: Frrat Üniversitesi örneği. Turkish Journal of Educational Studies, 7(2), 78-98.

Demir, F. ve Özdaş, F. (2020). Covıd-19 sürecindeki uzaktan eğitime ilişkin öğretmen görüşlerinin incelenmesi. Milli Ĕ̆itim Dergisi, 49(1), 273-292.

Dündar, S., Candemïr, Ö., Demïray, E., Genç-Kumtepe, E., Öztürk, S., Sağlık-Terlemez, M. ve Ulutak, İ. (2017). Anadolu Üniversitesi çalışanlarının açık ve uzaktan öğretime ilişkin tutumları. Açıkögretim Uygulamaları ve Araştırmaları Dergisi, 3(4), 187-227.

Emin, M. N. (2020). Koronavirüs salgını ve acil durumda eğitim. Seta Perspektif, 268, 1-4.

Erdemir, T. (2014). Uzaktan eğitim uygulamalarının etkililiği üzerine bir araştırma, (Yayınlanmamış Yüksek Lisans Tezi). Karadeniz Teknik Üniversitesi, Eğitim Bilimleri Enstitüsü, Trabzon.

Esgice, M. (2015). Açık ve uzaktan eğitim öğrencilerinin okul bırakma sebepleri, (Yüksek Lisans Tezi). Atatürk Üniversitesi, Eğitim Bilimleri Enstitüsü, Erzurum.

Garrison, D. R., Anderson, T. ve Archer, W. (2000). Critical inquiry in a text-based environment: Computer conferencing in higher education. The Internet and Higher Education, 2, 1-19.

Geray, H. (2004). Toplumsal araştırmalarda nicel ve nitel yöntemlere giriş: İletişim alanından örneklerle. Ankara: Siyasal Kitabevi.

Gökçe, A. (2008). Küreselleşme sürecinde uzaktan eğitim. Dicle Üniversitesi Ziya Gökalp Eğitim Fakültesi Dergisi, 11(10), 10-21.

Gülbahar, Y. (2012). E-öğrenme ortamlarında katılımcıların hazır bulunuşluk ve memnuniyet düzeylerinin ölçülmesi için ölçek geliştirme çalışması. Ankara Üniversitesi Ĕ̆itim Bilimleri Fakültesi Dergisi, 45(2), 119-137.

Haznedar, Ö. ve Baran, B. (2012). Eğitim Fakültesi öğrencileri için e-öğrenmeye yönelik genel bir tutum ölçeği geliştirme çalışması. Eğitim Teknolojisi Kuram ve Uygulama, 2(2), 42-59. 
İçten, T. (2006). Uzaktan eğitim öğrencileri için web tabanlı çevrimiçi sınav sistemi uygulaması geliştirilmesi, (Yüksek Lisans Tezi). Gazi Üniversitesi, Fen Bilimleri Enstitüsü, Ankara.

Karasar, N. (2018). Bilimsel araştırma yöntemi. Ankara: Nobel Akademik Yayıncılık.

Kaya, Z. (2002). Uzaktan eğitim. Ankara: Pegem A Yayıncılık.

Keskin, M. ve Kaya, Ö. D. (2020). Covid-19 sürecinde öğrencilerin web tabanlı uzaktan eğitime yönelik geri bildirimlerinin değerlendirilmesi. İzmir Kâtip Çelebi Üniversitesi Să̆lık Bilimleri Fakültesi Dergisi, 5(2), 60-73.

Lau, J., Yang. B. ve Dasgupta, R. (2020). Will the coronavirus make online education go viral? Times Higher Education, 47, 777-780. https://www.timeshighereducation.com/features/will-coronavirus-make-onlineeducation-go-viral adresinden erişilmiştir.

Moore, M. G. (1989). Three types of interaction. The American Journal of Distance Education, 3(2), $1-6$.

Nichols, M. (2003). A theory of elearning. Educational Technology E Society, 6(2), 1-10.

Orhan, F. ve Akkoyunlu, B. (1999). Uzaktan eğitim yaklaşımında temel eğitim 1.kademe öğretmenlerinin video destekli hizmet içi eğitimi. Hacettepe Üniversitesi Eğitim Fakültesi Dergisi, 17(17), 18-32.

Özbay, Ö. (2015). Dünyada ve Türkiye' de uzaktan eğitimin güncel durumu. Uluslararası Ĕ̆itim Bilimleri Dergisi, 2(5), 376-394.

Şen, B., Atasoy, F. ve Aydın, N. (2010). Düşük maliyetli web tabanlı uzaktan eğitim sistemi uygulaması. 12. Akademik Bilişim Konferansı, Muğla.

Telli, S. ve Altun, D. (2020). Coronavirüs ve çevrimiçi (online) eğitimin önlenemeyen yükselişi. Üniversite Araştırmaları Dergisi, 3(1), 25-34.

Topçu, N. (2017). İsyan ahlakı. İstanbul: Dergah Yayınları.

Ural, Y. (2005). Segmenting youth market based on beliefs related to high technology: A study from Turkey. Çukurova Üniversitesi Sosyal Bilimler Enstitüsü Dergisi, 14(2), 421-435.

Uşun, S. (2006). Uzaktan eğitim. Ankara: Nobel Yayın Dağıtım.

Valentiner, D. (2002). Distance learning: Promises, problems, and possibilities. Online Journal of Distance Learning Administration, 5(3), 1-11. 
Yadigar, G. (2010). Uzaktan eğitim uygulamalarının etkililiği üzerine bir araştırma, (Yayınlanmamış Yüksek Lisans Tezi). Gazi Üniversitesi, Eğitim Bilimleri Enstitüsü, Ankara.

Yıldız, M. (2015). Uzaktan eğitim programlarında ders veren öğretim elemanlarının uzaktan eğitime yönelik bilgi, inanç ve uygulamaları arasındaki ilişkiler, (Yüksek Lisans Tezi). Hacettepe Üniversitesi, Eğitim Bilimleri Enstitüsü, Ankara.

Yıldız, S. (2016). Pedogojik formasyon eğitimi alan öğrencilerin uzaktan eğitime yönelik tutumları. Bolu Abant İzet Biaysal Üniversitesi Sosyal Bilimler Enstitüsü Dergisi, 16(1), 301-329. 